\title{
Gravidez na Adolescência
}

Segundo dados do Ministério da Saúde, estima-se que dois terços das mulheres que dêem a luz no Brasil tem idade variável entre 10 e 19 anos. Confrontando com a Holanda, onde esta cifra é da ordem de 7 por 1000 adolescentes e nos Estados Unidos de 54/ 1000 (Eurostat - The Washington Times, novembro 1999), podemos aquilatar a dimensão social e as repercussões orgânicas, psicológicas e emocionais para a adolescente que a gestação precoce representa em nosso país.

A Federação Brasileira das Sociedades de Ginecologia e Obstetrícia, preocupada com estes elevados índices e levando em consideração os resultados das campanhas realizadas pela Holanda e Estados Unidos que, baseadas na sensibilização e educação do adolescente, alcançaram esses indices depois de 15 anos (a incidência era de 34 / 1000 na Holanda e nos Estados Unidos de $120 / 1000$ em 1984), conclama a todos a se unirem para colaborar na prevenção destas gestações, na maioria das vezes indesejadas.

\section{A Diretoria}

